Journal of Bangladesh Academy of Sciences, Vol. 38, No. 1, 27-37, 2014

\title{
PERFORMANCE OF GERBERA CULTIVARS UNDER DIFFERENT WAVELENGTHS OF SOLAR SPECTRUM
}

\author{
H. MEHRAJ, T. TAUFIQUE, A.F. ONA, A. NUSRAT AND A.F.M. JAMAL UDDIN* \\ Department of Horticulture, Sher-e-Bangla Agricultural University, \\ Dhaka-1207, Bangladesh
}

\begin{abstract}
To find out the response of potted gerbera under different light spectrum wavelengths of solar radiation was carried out. Three gerbera cultivars viz. $\mathrm{V}_{1}$ (red), $\mathrm{V}_{2}$ (pink), $\mathrm{V}_{3}$ (brick red) and seven treatments viz. $\mathrm{L}_{1}$ (full spectrum), $\mathrm{L}_{2}$ (no spectrum), $\mathrm{L}_{3}$ (cut of 380 - $750 \mathrm{~nm}$ wavelength), $\mathrm{L}_{4}$ (cut of 620 - $750 \mathrm{~nm}$ wavelength), $\mathrm{L}_{5}$ (cut of 450 - $495 \mathrm{~nm}$ wavelength), $\mathrm{L}_{6}$ (cut of $495-570 \mathrm{~nm}$ wavelength) and $\mathrm{L}_{7}$ (cut of $570-590 \mathrm{~nm}$ wavelength) were exerted on the experiment. Among the cultivars brick red was the best one. Plants were green because they reflected $495-570 \mathrm{~nm}$ wavelengths (green band) from the visible spectrum of solar radiation. Current findings indicated that of 495 - $570 \mathrm{~nm}$ wavelengths (green band), the plants responded alike to the full spectrum. No spectrum provided the worst result in all attributes of gerbera. Number of flower, peduncle length, peduncle diameter, flower head diameter and bending percentage were least after no spectrum in all the treatments. All the treatments except full spectrum and of $495-570 \mathrm{~nm}$ wavelength (green band) restricted for the entrance of the $620-750 \mathrm{~nm}$ wavelength (red band); $620-750 \mathrm{~nm}$ wavelength (red band) of light was very important for the plants. Besides, absence of $620-750 \mathrm{~nm}$ wavelengths (red band) and 450 - $495 \mathrm{~nm}$ wavelength (blue band) drastically hampered plant growth, yield and quality contributing characters.
\end{abstract}

Key words: Gerbera, Variety, Light wavelength, Growth

\section{INTRODUCTION}

Gerbera (Gerbera jamesonii L.) belongs to Asteraceae, is a popularly known cut flower. Plants depend on light as their ultimate source of energy. Photosynthesis converts light energy into chemical energy required for plant growth and development. Light travels in packets of energy called photons. Each photon has a specific energy related to a certain frequency or wavelength. Plants are exquisitely sensitive to both the quality and quantity of light. Light quality, also called spectral composition and spectral energy distribution (SED), refers to the composition of light as to wavelengths that are effective in photosynthesis and other plant growth processes. The wavelengths with primary

\footnotetext{
* Correspondence author: < jamal4@yahoo.com>.
} 
importance in photobiology are the ultraviolet (UV), visible light, and infrared (IR) (Hopkins 1999) and the wavelengths between 300 and $900 \mathrm{~nm}$ are capable of affecting plant growth (Devlin 1975). Sunlight consists of about 4\% ultraviolet radiation, 52\% infrared radiation, and 44\% visible light (Moore et al. 2003). Only light that is absorbed can have an effect and the visible light that is reflected is the one that is perceived by the naked eye. Visible light consists of wavelengths ranging 380 to $750 \mathrm{~nm}$ which is just a small section of the entire electromagnetic spectrum of solar radiation. Visible light corresponds roughly to the photosynthetically active radiation (PAR) from 400 to 700 $\mathrm{nm}$. These wavelengths contain the right amounts of energy for the physiological and biochemical processes, their relative proportion in the available light is of prime importance in determining light quality. However, individually, each light wavelength contains different properties that produces a variety of results that vary from its predecessor, and plants respond to the quality (spectral distribution) of the incident light which can be mediated by inhibition of specific wavelength for improving the utilization of solar radiation by agricultural crops. Hunter and Burritt (2004) found that blue light inhibited shoot production while red light either promoted production or had no effect on lettuce plants. Cleland and Briggs (1967) noticed an improved flowering response under continuous red light treatment. However, there are reports that the combined lights of white light have more significant results compared to red and blue combined (Rajasekhar and Sopory 1985). But, other studies and Sopory concluded that the effects of light quality on plant growth were generally dependent on genotype (Latkowska et al. 1999). Besides, gerbera varieties varied significantly on growth and flower yield performances (Das et al. 2012). Keeping these points in view, present study was conducted to find out the response of potted gerbera varieties under different light spectrum wavelengths of solar radiation.

\section{MATERIALS AND METHODS}

The study was conducted at the Horticulture Farm, Sher-e-Bangla Agricultural University, Dhaka, Bangladesh during December 2012 to June 2013 to find out growth and yield performance of potted gerbera against different light spectrum wavelengths of solar radiation. The two factorial experiments were laid out in complete randomized design (CRD) with five replications. Same aged seedlings were collected from local nursery, Dhaka. Soil and cow-dung $(1: 1)$ were mixed and pots were filled 7 days before transplanting. Recommended chemical fertilizers (NPK as 5, 10, and $5 \mathrm{~g}$, respectively in each pot) were mixed with the soil. Three varieties were used in the experiment and these were symbolized by $\mathrm{V}_{1}$ (red), $\mathrm{V}_{2}$ (pink) and $\mathrm{V}_{3}$ (brick red). On the other hand, different wavelengths were cut from light spectrum of solar radiation and these were symbolized by $\mathrm{L}_{1}$ (Full spectrum), $\mathrm{L}_{2}$ (no spectrum; black), $\mathrm{L}_{3}$ (cut of $380-750 \mathrm{~nm}$ wavelength; 
white), $\mathrm{L}_{4}$ (cut of 620 - $750 \mathrm{~nm}$ wavelength; red), $\mathrm{L}_{5}$ (cut of 450 - $495 \mathrm{~nm}$ wavelength; blue), $\mathrm{L}_{6}$ (cut of $495-570 \mathrm{~nm}$ wavelength; green), $\mathrm{L}_{7}$ (cut of $570-590 \mathrm{~nm}$ wavelength; yellow). Cut of different wavelengths was ensured by Spectrometer MR16. Data were collected on number of leaves, plant height, leaf area, chlorophyll percentage, days to first flower bud initiation, number of flower, peduncle length, peduncle diameter, flower head diameter and peduncle bending percentage from each pot within the period. Number of leaves, plant height and leaf area were measured at every 30 days interval from 30 DAT and continued up to 120 DAT. Leaf area, chlorophyll percentage and peduncle diameter were measured by using CL-202 Leaf Area Meter, SPAD-502 Chlorophyll Meter and Digital Caliper-515 (DC-515), respectively. Chlorophyll percentage and peduncle diameter were measured at 90 DAT and full bloomed stage, respectively. All parameters were statistically analyzed by using MSTAT-C program. Mean for all the treatments was calculated, analysis of variance for each of the characters was performed by F-test and difference between treatments was evaluated by Least Significant Difference (LSD) at the 5\% level of significance (Gomez and Gomez 1984).

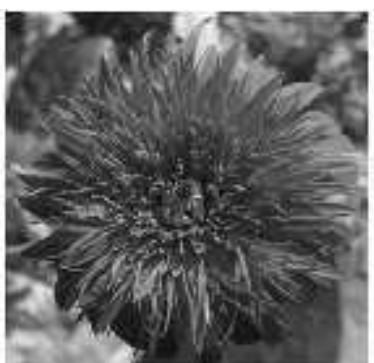

$v_{3}$

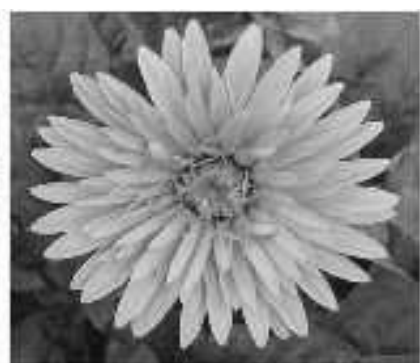

$v_{2}$

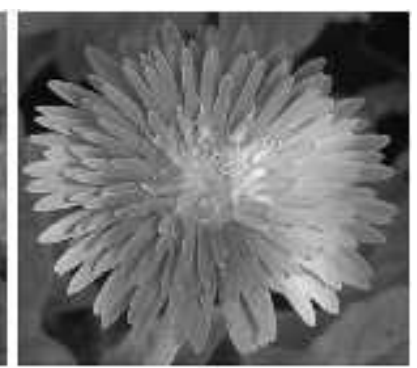

$v_{3}$

Fig. 1. Number of leaves in different varieties of gerbera.

\section{RESULT AND DISCUSSION}

Leaf number of gerbera varied significantly among the varieties, treatments and their combinations at 120 days after transplanting. However, maximum number of leaves (36.4) was found in $V_{1}$ whereas minimum (29.0) in $V_{3}$ (Fig. 1a). In case of different treatments, maximum number of leaves (35.2) was obtained from $\mathrm{L}_{1}$ while minimum (28.3) from $L_{2}$ (Fig. 2b). Minimal amount of blue and red light reach the plants that grow under a canopy because it is absorbed by the chlorophyll-containing leaves at the higher level (Hopkins 1999) and for that reason growth of the most of the plants grown under canopy is less. In this case it is clear that blue band and red band of the light is more important. Among the treatment combination, it was found that $\mathrm{V}_{1} \mathrm{~L}_{4}$ and $\mathrm{V}_{1} \mathrm{~L}_{6}$ both combinations provided maximum number of leaves (38.3) whereas minimum (23.7) from $\mathrm{V}_{3} \mathrm{~L}_{2}$ (Fig. 2c). 

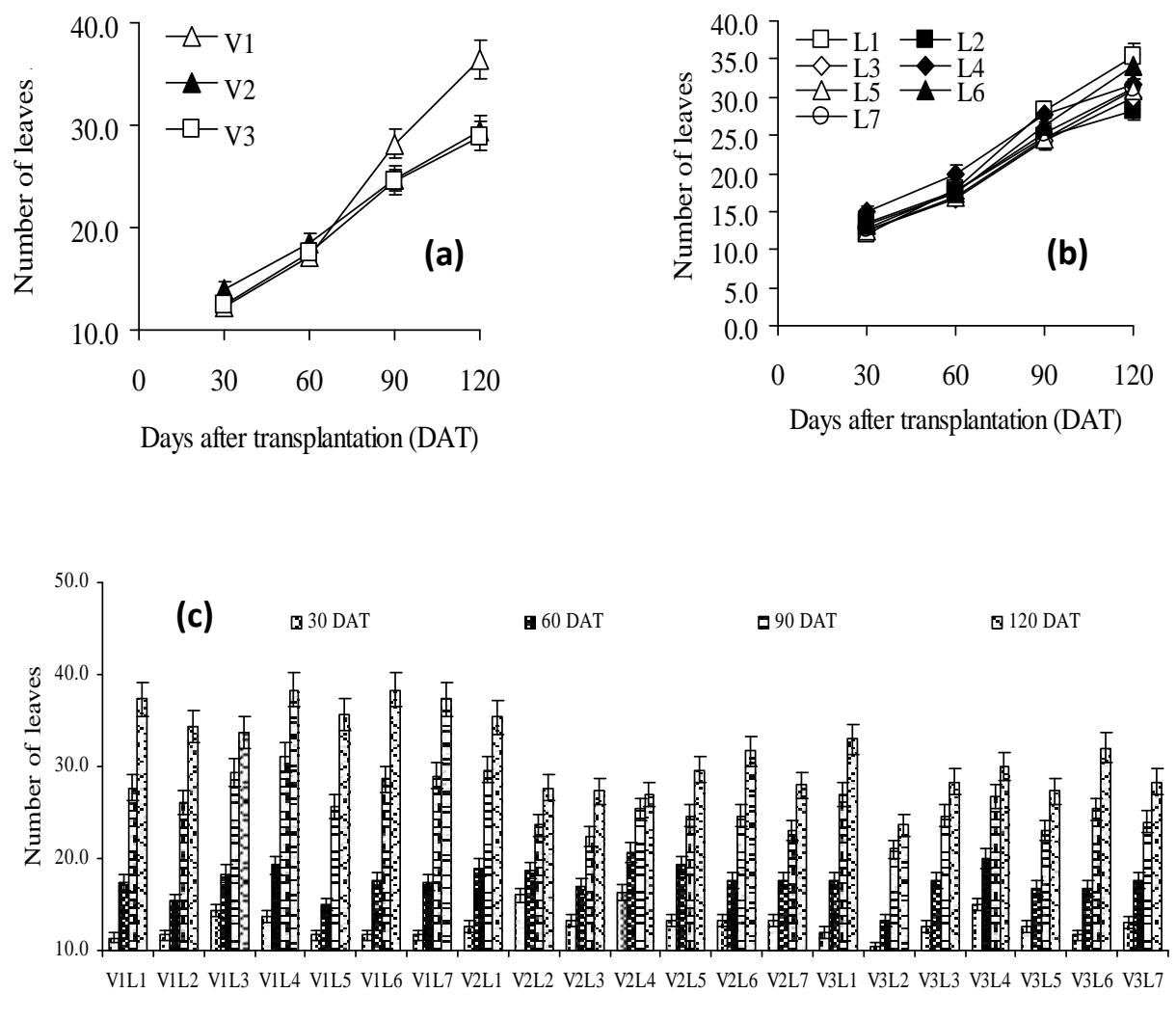

Fig. 2. Effects of (a) variety, (b) treatments and (c) combinations on number of leaves at different days after transplantation (DAT). $\mathrm{V}_{1}$ (red), $\mathrm{V}_{2}$ (pink) and $\mathrm{V}_{3}$ (brick red); $\mathrm{L}_{1}$ (full spectrum), $\mathrm{L}_{2}$ (no spectrum; black), $\mathrm{L}_{3}$ (cut of $380-750 \mathrm{~nm}$ wavelength; white), $\mathrm{L}_{4}$ (cut of 620 - $750 \mathrm{~nm}$ wavelength; red), $\mathrm{L}_{5}$ (cut of $450-495 \mathrm{~nm}$ wavelength; blue), $\mathrm{L}_{6}$ (cut of 495 - $570 \mathrm{~nm}$ wavelength; green), $\mathrm{L}_{7}$ (cut of 570 - 590 nm wavelength; yellow).

Plant height of gerbera varied significantly among the different varieties, treatments and their combinations at different days after transplanting. Tallest plant $(42.9 \mathrm{~cm})$ was found in $\mathrm{V}_{1}$, whereas smallest plant $(33.9 \mathrm{~cm})$ in $\mathrm{V}_{3}$ (Fig. 3a). In case of different treatments, tallest plant $(47.1 \mathrm{~cm})$ was obtained in $\mathrm{L}_{2}$ while smallest plant $(30.1 \mathrm{~cm})$ in $\mathrm{L}_{1}$ (Fig. 3b). Yerima et al. (2012) found variation on plant height on Roselle (Hibiscus sabdariffa) due to the different light colour (wavelength). $\mathrm{L}_{2}$ may be provided the tallest plant to search for light spectrum. Among the treatment combination, it was observed that $\mathrm{V}_{1} \mathrm{~L}_{2}$ combination provided longest plant $(55.2 \mathrm{~cm}$ at 120 days after transplanting). On the other hand, $\mathrm{V}_{3} \mathrm{~L}_{1}$ treatment combination gave smallest plant $(27.1 \mathrm{~cm}$ at 120 days after transplantation) (Fig. 3c). 


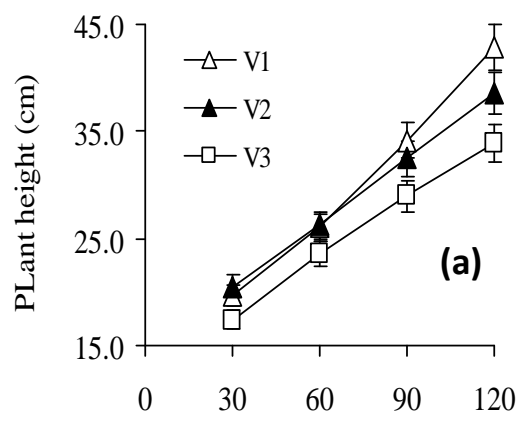

Days after transplantation (DAT)

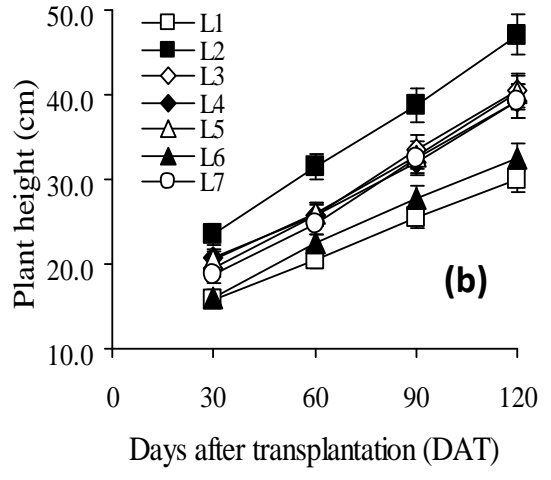

(b)

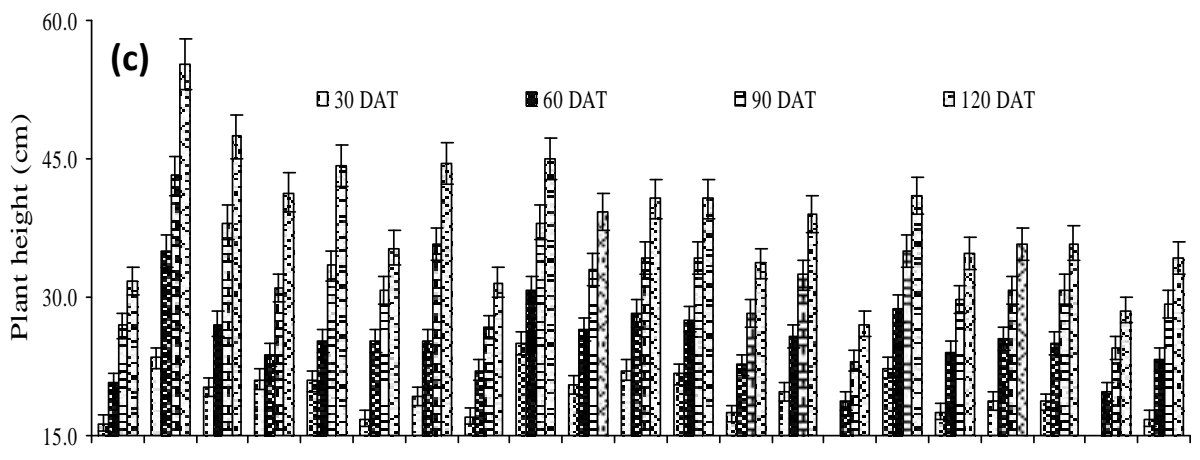

V1L1 V1L2 V1L3 V1L4 V1L5 V1L6 V1L7 V2L1 V2L2 V2L3 V2L4 V2L5 V2L6 V2L7 V3L1 V3L2 V3L3 V3L4 V3L5 V3L6 V3L7

Treatment combination

Fig. 3. Effects of (a) variety, (b) treatments and (c) combinations on plant height at different days after transplantation (DAT). $\mathrm{V}_{1}$ (red), $\mathrm{V}_{2}$ (pink) and $\mathrm{V}_{3}$ (brick red); $\mathrm{L}_{1}$ (Full spectrum), $\mathrm{L}_{2}$ (No spectrum; Black), $\mathrm{L}_{3}$ (cut of 380 - $750 \mathrm{~nm}$ wavelength; white), $\mathrm{L}_{4}$ (cut of 620 - $750 \mathrm{~nm}$ wavelength; red), $\mathrm{L}_{5}$ (cut of $450-495 \mathrm{~nm}$ wavelength; blue), $\mathrm{L}_{6}$ (cut of 495 - $570 \mathrm{~nm}$ wavelength; green), $\mathrm{L}_{7}$ (cut of 570 - 590 $\mathrm{nm}$ wavelength; yellow).

Leaf area among the gerbera varieties, treatments and their combinations varied significantly at different days after transplantation. Maximum leaf area $\left(37.9 \mathrm{~cm}^{2}\right)$ was observed in $\mathrm{V}_{3}$ whereas minimum $\left(33.6 \mathrm{~cm}^{2}\right)$ in $\mathrm{V}_{1}$ (Fig. 4a). On the other hand, among the treatments $\mathrm{L}_{1}$ provided maximum leaf area $\left(42.0 \mathrm{~cm}^{2}\right)$ followed by $\mathrm{L}_{6}\left(40.1 \mathrm{~cm}^{2}\right)$, whereas minimum $\left(29.0 \mathrm{~cm}^{2}\right)$ in $\mathrm{L}_{2}$ (Fig. 4b). Between treatment combinations, maximum leaf area $\left(44.4 \mathrm{~cm}^{2}\right)$ was recorded in $\mathrm{V}_{3} \mathrm{~L}_{1}$, whereas minimum $\left(26.9 \mathrm{~cm}^{2}\right)$ in $\mathrm{V}_{1} \mathrm{~L}_{2}$ (Fig. 4c). 


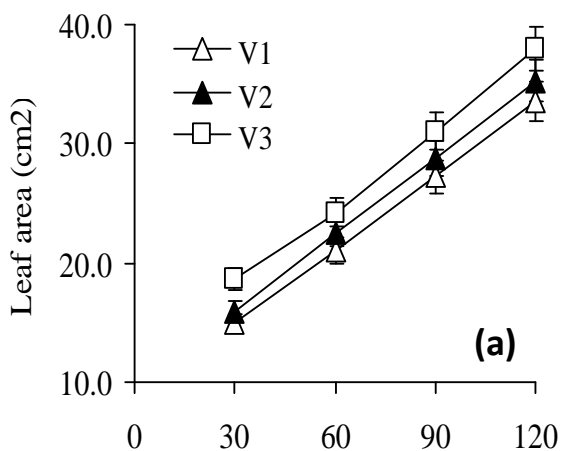

Days after transplantation (DAT)

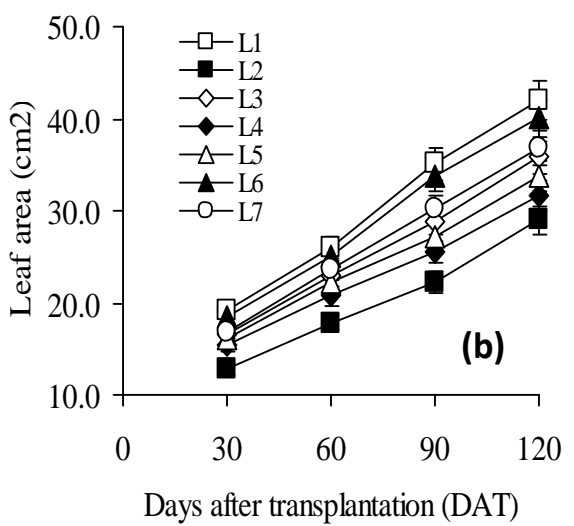

घ90 DAT $\square 120$ DAT

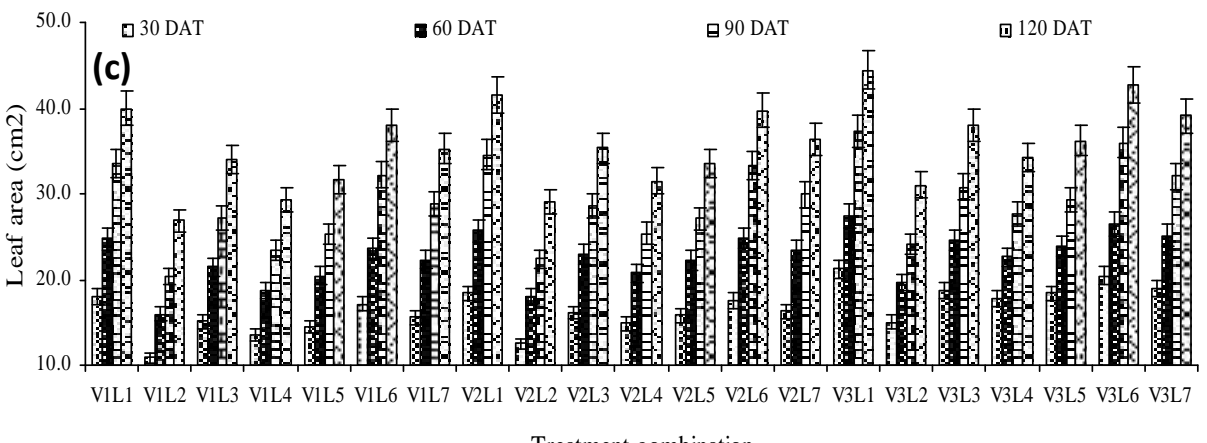

Treatment combination

Fig. 4. Effects of (a) variety, (b) treatments and (c) combinations on leaf area at different days after transplantation (DAT). $\mathrm{V}_{1}$ (red), $\mathrm{V}_{2}$ (pink) and $\mathrm{V}_{3}$ (brick red); $\mathrm{L}_{1}$ (full spectrum), $\mathrm{L}_{2}$ (no spectrum; black), $\mathrm{L}_{3}$ (cut of $380-750 \mathrm{~nm}$ wavelength; white), $\mathrm{L}_{4}$ (cut of 620 - $750 \mathrm{~nm}$ wavelength; red), $\mathrm{L}_{5}$ (cut of $450-495 \mathrm{~nm}$ wavelength; blue), $\mathrm{L}_{6}$ (cut of 495 - $570 \mathrm{~nm}$ wavelength; green), $\mathrm{L}_{7}$ (cut of 570 - $590 \mathrm{~nm}$ wavelength; yellow)

Chlorophyll content (\%) among the gerbera varieties, treatments and their combinations differed significantly at different days after transplantation. Maximum chlorophyll content $(37.4 \%)$ was found in $\mathrm{V}_{3}$, while minimum $(35.1 \%)$ in $\mathrm{V}_{1}$ (Table $1 \mathrm{a}$ ). Maximum chlorophyll content $(46.2 \%)$ was provided by $\mathrm{L}_{1}$, followed by $\mathrm{L}_{6}(42.6 \%)$, whereas minimum (27.5\%) from $\mathrm{L}_{2}$ (Table $1 \mathrm{~b}$ ). Total chlorophyll content varied due to the different light wavelengths on cattleya culture in vitro (Cybularz-Urban et al. 2007). Photosynthetic pigment levels were lower under illumination with monochromatic light than under white light, but in terms of the analyzed plant material's morphological and anatomical features, irradiation with blue monochromatic light was most favorable for Cattleya intermedia $\times$ Cattleya aurantiaca cultures (Cybularz-Urban et al. 2007). Green light wavelength is was found to be least effective for photosynthesis; it is mostly 
transmitted or reflected by the plant. It is the reflection of the $495-570 \mathrm{~nm}$ wavelengths (green band) from most leaves that gives the visual sensation of green color. For this reason, $\mathrm{L}_{6}$ (protection of $495-570 \mathrm{~nm}$ wavelength) provided the highest chlorophyll percentage after $L_{1} . L_{3}$ provided $38.1 \%$ chlorophyll as it protects to the entrance of 380$750 \mathrm{~nm}$ wavelength, but here plant got thered wavelength. $\mathrm{L}_{4}, \mathrm{~L}_{5}$ and $\mathrm{L}_{7}$ provided $31.8 \%$, $34.6 \%$ and $32.8 \%$ chlorophyll respectively. $620-750 \mathrm{~nm}$ (red band) and $450-495 \mathrm{~nm}$ (blue band) wavelengths are active in photo morphogenesis, the regulation of plant development by light. $\mathrm{L}_{7}$ also protect to the entrance of wavelength $620-750 \mathrm{~nm}$ (red band) and wavelength $495-570 \mathrm{~nm}$ (green band). Among the treatment combinations, $\mathrm{V}_{3} \mathrm{~L}_{1}$ gave the maximum chlorophyll content $(47.5 \%)$ followed by $\mathrm{V}_{2} \mathrm{~L}_{1}(46.2 \%)$, on the other hand minimum chlorophyll content $(26.5 \%)$ was provided by $\mathrm{V}_{1} \mathrm{~L}_{2}$ (Table 1c).

Among the gerbera varieties, treatments and their combinations days required for initiating flower buds varied significantly. Earliest (102.6 days) bud initiating variety was $V_{3}$ where $V_{1}$ (110.6 days) was the late one (Table 1a). Kandpal et al. (2003) reported that variation in first harvest among the cultivars due to the genetic make up of the varieties. $\mathrm{L}_{1}$ took the maximum days (116.2) for flower bud initiation, while $\mathrm{L}_{2}$ took minimum days (97.8) (Table 1b). Except black shade, current study showed that blue yellow and green light shade caused delay flowering. Blue and yellow both net shade stimulation and delay of flowering (Shahak et al. 2004). As the plants did not get the sufficient light for their vigorous growth in $\mathrm{L}_{2}$ treatment, they went to the reproduction stage. On the other hand, $\mathrm{V}_{1} \mathrm{~L}_{1}$ required maximum days (120.3) for flower bud initiation followed by $\mathrm{V}_{2} \mathrm{~L}_{1}$ (116.3 days), whereas minimum days (94.0) required from $\mathrm{V}_{3} \mathrm{~L}_{2}$ (Table 1c).

Number of flowers differed significantly among the gerbera varieties, treatments and their combinations at different days after transplantation. Maximum number of flowers (16.7) was found from $V_{3}$ while minimum (12.1) from $V_{1}$ (Table 1a). Maximum numbers of flowers (18.1) provided by $\mathrm{L}_{1}$ followed by $\mathrm{L}_{6}$ (17.6) whereas minimum (10.4) from $\mathrm{L}_{2}$ (Table $1 b$ ). $\mathrm{L}_{1}$ (full spectrum) and $\mathrm{L}_{6}$ (cut of $495-570 \mathrm{~nm}$ wavelengths) have no significant variation that indicates that (green band) is not too much essential for the flowering on gerbera plants; 620 - $750 \mathrm{~nm}$ wavelengths are the red band and $450-495 \mathrm{~nm}$ wavelength is the blue band. Green light is reflected by plants due to the chlorophyll being unable to absorb the specific fraction of the light spectrum (Whiting 2007). Large amount of absorption by chlorophyll of these two band occurred in plant and most significant influence on photosynthesis thus promotes flowering and budding. All treatments except $\mathrm{L}_{1}$ and $L_{6}$ inhibited either red band or blue band or both and for that reason $L_{1}$ and $L_{6}$ did not show the significant variation. Among the treatment combinations, $\mathrm{V}_{3} \mathrm{~L}_{1}$ gave the maximum number of flowers (20.3) followed by $\mathrm{V}_{3} \mathrm{~L}_{6}$ (19.7), on the other hand minimum number of flowers (8.0) provided by $\mathrm{V}_{1} \mathrm{~L}_{2}$ (Table 1c). 
Peduncle length differed significantly among the gerbera varieties, treatments and their combinations. Longest peduncle $(32.6 \mathrm{~cm})$ was found in $\mathrm{V}_{3}$ while shortest $(26.4 \mathrm{~cm})$ in $\mathrm{V}_{1}$ (Table 1a). Ambad et al. (2001) and Kandpal et al. (2003) also reported the variation in stalk length among the genotypes due to the genetic characters of particular genotype. Longest peduncle $(36.2 \mathrm{~cm})$ was provided by $\mathrm{L}_{1}$ followed by $\mathrm{L}_{6}(34.3 \mathrm{~cm})$, whereas shortest $\left(23.5 \mathrm{~cm}\right.$ ) from $\mathrm{L}_{2}$ (Table $1 \mathrm{~b}$ ); 620 - $750 \mathrm{~nm}$ wavelengths (red band) significantly influenced the peduncle length of gerbera. Among the treatment combinations, $\mathrm{V}_{3} \mathrm{~L}_{1}$ gave the longest peduncle $(39.8 \mathrm{~cm})$ followed by $\mathrm{V}_{3} \mathrm{~L}_{6}(37.4 \mathrm{~cm})$, on the other hand shortest peduncle $(20.3 \mathrm{~cm})$ was provided by $\mathrm{V}_{1} \mathrm{~L}_{2}$ (Table $\left.1 \mathrm{c}\right)$.

Table 1a. Effects of variety to the different attributes of gerbera.

\begin{tabular}{|c|c|c|c|c|c|c|c|c|c|c|c|c|c|c|}
\hline \multirow{2}{*}{$\begin{array}{l}\text { Variety } \\
\mathrm{V}_{1}\end{array}$} & \multicolumn{2}{|c|}{$\begin{array}{l}\mathrm{CH} \% \text { at } \\
90 \mathrm{DAT}\end{array}$} & \multicolumn{2}{|c|}{$\begin{array}{l}\text { Days to } \\
\text { flower bud } \\
\text { initiation }\end{array}$} & \multicolumn{2}{|c|}{$\begin{array}{l}\text { Number } \\
\text { of flower }\end{array}$} & \multicolumn{2}{|c|}{$\begin{array}{l}\text { Peduncle } \\
\text { length } \\
(\mathrm{cm})\end{array}$} & \multicolumn{2}{|c|}{$\begin{array}{c}\text { Peduncle } \\
\text { diameter } \\
(\mathrm{mm})\end{array}$} & \multicolumn{2}{|c|}{$\begin{array}{l}\text { Flower head } \\
\text { diameter } \\
(\mathrm{cm})\end{array}$} & \multicolumn{2}{|c|}{$\begin{array}{c}\text { Bending } \\
(\%)\end{array}$} \\
\hline & 35.1 & $c$ & 110.6 & $\mathrm{a}$ & 12.1 & $\mathrm{c}$ & 26.4 & $\mathrm{c}$ & 2.3 & $\mathrm{c}$ & 8.7 & $\mathrm{c}$ & 37.7 & $\mathrm{a}$ \\
\hline $\mathrm{V}_{2}$ & 36.2 & b & 106.9 & $\mathrm{~b}$ & 14.8 & b & 30.3 & b & 2.6 & b & 9.4 & $\mathrm{~b}$ & 36.7 & b \\
\hline $\mathrm{V}_{3}$ & 37.4 & $\mathrm{a}$ & 102.6 & $\mathrm{c}$ & 16.7 & a & 32.6 & a & 2.8 & $\mathrm{a}$ & 10.2 & $\mathrm{a}$ & 35.7 & $\mathrm{c}$ \\
\hline LSD 0.05 & 0.3 & & 0.2 & & 0.4 & & 0.4 & & 0.1 & & 0.1 & & 0.1 & \\
\hline $\mathrm{CV} \%$ & 1.4 & & 0.3 & & 4.5 & & 2.1 & & 3.4 & & 1.4 & & 0.1 & \\
\hline
\end{tabular}

Peduncle diameter differed significantly among the gerbera varieties, treatments and their combinations. Highest peduncle diameter $(2.8 \mathrm{~mm})$ was found in $\mathrm{V}_{3}$, while lowest (2.3 mm) in $\mathrm{V}_{1}$ (Table 1a). Eberhardt (1982) and Jeevajothi et al. (2003) in gerbera also found the variation in peduncle diameter on different gerbera genotypes. Uppermost peduncle diameter $(3.2 \mathrm{~mm})$ was provided by $\mathrm{L}_{1}$ whereas lowest $(2.0 \mathrm{~mm})$ from $\mathrm{L}_{2}$ (Table 1b). Among the treatment combinations, $\mathrm{V}_{3} \mathrm{~L}_{1}$ gave the highest peduncle diameter $(3.4$ $\mathrm{mm})$ followed by $\mathrm{V}_{3} \mathrm{~L}_{6}(3.3 \mathrm{~mm})$, on the other hand shortest peduncle $(1.8 \mathrm{~mm})$ was provided by $\mathrm{V}_{1} \mathrm{~L}_{2}$ (Table $\left.1 \mathrm{c}\right)$.

Table 1b. Effects of different treatments on different attributes of gerbera.

\begin{tabular}{|c|c|c|c|c|c|c|c|c|c|c|c|c|c|c|}
\hline \multirow{2}{*}{$\begin{array}{l}\text { Treatments } \\
\mathrm{L}_{1}\end{array}$} & \multirow{2}{*}{$\begin{array}{c}\mathrm{CH} \% \\
\text { at } 90 \\
\text { DAT } \\
46.2\end{array}$} & \multicolumn{2}{|c|}{$\begin{array}{l}\text { Days to } \\
\text { flower bud } \\
\text { initiation }\end{array}$} & \multicolumn{3}{|c|}{$\begin{array}{l}\text { Number of } \\
\text { flower }\end{array}$} & \multirow{2}{*}{$\begin{array}{c}\begin{array}{c}\text { Peduncle } \\
\text { length } \\
(\mathrm{cm})\end{array} \\
36.2\end{array}$} & \multicolumn{2}{|c|}{$\begin{array}{l}\text { Peduncle } \\
\text { diameter } \\
(\mathrm{mm})\end{array}$} & \multicolumn{3}{|c|}{$\begin{array}{c}\text { Flower head } \\
\text { diameter }(\mathrm{cm})\end{array}$} & \multicolumn{2}{|c|}{$\begin{array}{l}\text { Bending } \\
(\%)\end{array}$} \\
\hline & & $\mathrm{a}$ & 116.2 & $\mathrm{a}$ & 18.1 & $\mathrm{a}$ & & $\mathrm{a}$ & 3.2 & $\mathrm{a}$ & 10.5 & $\mathrm{a}$ & 5.4 & $\mathrm{~g}$ \\
\hline $\mathrm{L}_{2}$ & 27.5 & $\mathrm{~g}$ & 97.8 & $g$ & 10.4 & $\mathrm{f}$ & 23.5 & $\mathrm{~g}$ & 2.0 & $\mathrm{f}$ & 7.9 & $\mathrm{e}$ & 70.0 & $\mathrm{a}$ \\
\hline $\mathrm{L}_{3}$ & 38.1 & c & 102.2 & $\mathrm{f}$ & 12.4 & $\mathrm{e}$ & 26.8 & $\mathrm{f}$ & 2.5 & d & 9.6 & $\mathrm{c}$ & 49.3 & b \\
\hline $\mathrm{L}_{4}$ & 31.8 & f & 104.2 & $\mathrm{e}$ & 13.1 & d & 27.6 & $\mathrm{e}$ & 2.7 & $\mathrm{c}$ & 9.3 & d & 40.9 & d \\
\hline $\mathrm{L}_{5}$ & 34.6 & d & 106.2 & d & 14.4 & $\mathrm{c}$ & 31.7 & $\mathrm{c}$ & 2.5 & d & 9.5 & $\mathrm{c}$ & 46.0 & $\mathrm{c}$ \\
\hline $\mathrm{L}_{6}$ & 42.6 & $\mathrm{~b}$ & 111.1 & b & 17.6 & $\mathrm{a}$ & 34.3 & $\mathrm{~b}$ & 3.0 & b & 9.9 & $\mathrm{~b}$ & 16.4 & f \\
\hline $\mathrm{L}_{7}$ & 32.8 & e & 109.1 & $\mathrm{c}$ & 15.8 & $\mathrm{~b}$ & 28.3 & d & 2.3 & $\mathrm{e}$ & 9.3 & d & 29.0 & $\mathrm{e}$ \\
\hline LSD 0.05 & 0.5 & & 0.4 & & 0.6 & & 0.6 & & 0.1 & & 0.1 & & 0.1 & \\
\hline CV\% & 1.4 & & 0.3 & & 4.5 & & 2.1 & & 3.4 & & 1.4 & & 0.1 & \\
\hline
\end{tabular}

Flower head diameter differed significantly among the gerbera varieties, treatments and their combinations. Maximum diameter of flower head $(10.2 \mathrm{~cm})$ was found in $\mathrm{V}_{3}$ 
while lowest $(8.7 \mathrm{~cm})$ in $\mathrm{V}_{1}$ (Table 1a). Maximum diameter of flower head $(10.5 \mathrm{~cm})$ was provided by $\mathrm{L}_{1}$ followed by $\mathrm{L}_{6}(9.9 \mathrm{~cm})$, whereas lowest $(7.9 \mathrm{~cm})$ in $\mathrm{L}_{2}$ (Table $\left.1 \mathrm{~b}\right)$ in terms of treatments. Among the treatments, colour synthesis occurred only in $\mathrm{L}_{1}$ and $\mathrm{L}_{6}$. On the other hand, in all other treatments gerbera flower were not able to synthesize their exact colour. There have been studies where blue light was actually shown to have an increasing effect on stomatal openings which would greatly affect the photosynthesis in the leaves (Talbott et al. 2002). Even studying at the molecular level, blue light has been shown to increase the rate of transcription and RNA levels of pea plants (Marrs and Kaufman 1988). Among the combinations, $\mathrm{V}_{3} \mathrm{~L}_{1}$ gave the highest flower head diameter $(11.3 \mathrm{~cm})$ followed by $\mathrm{V}_{3} \mathrm{~L}_{6}(10.7 \mathrm{~cm})$, on the other hand minimum flower head diameter $(7.2 \mathrm{~cm})$ was provided by $\mathrm{V}_{1} \mathrm{~L}_{1}$ (Table $\left.1 \mathrm{c}\right)$.

Table 1c. Effects of different combinations on different attributes of gerbera.

\begin{tabular}{|c|c|c|c|c|c|c|c|c|c|c|c|c|c|c|}
\hline \multirow{2}{*}{$\begin{array}{l}\text { Combinations } \\
\mathrm{V}_{1} \mathrm{~L}_{1}\end{array}$} & \multicolumn{2}{|c|}{$\begin{array}{l}\mathrm{CH} \% \text { at } \\
90 \mathrm{DAT}\end{array}$} & \multicolumn{2}{|c|}{$\begin{array}{l}\text { Days to } \\
\text { flower bud } \\
\text { initiation }\end{array}$} & \multicolumn{2}{|c|}{$\begin{array}{l}\text { Number of } \\
\text { flower }\end{array}$} & \multicolumn{2}{|c|}{$\begin{array}{l}\text { Peduncle } \\
\text { length } \\
(\mathrm{cm})\end{array}$} & \multicolumn{2}{|c|}{$\begin{array}{l}\text { Peduncle } \\
\text { diameter } \\
(\mathrm{mm})\end{array}$} & \multicolumn{2}{|c|}{$\begin{array}{l}\text { Flower Head } \\
\text { diameter } \\
(\mathrm{cm})\end{array}$} & \multicolumn{2}{|c|}{$\begin{array}{c}\text { Bending } \\
(\%)\end{array}$} \\
\hline & 44.8 & $\mathrm{c}$ & 120.3 & a & 15.7 & def & 32.1 & $\mathrm{~d}$ & 2.9 & de & 9.8 & fg & 6.4 & $\mathrm{~s}$ \\
\hline $\mathrm{V}_{1} \mathrm{~L}_{2}$ & 26.5 & $\mathrm{p}$ & 101.0 & o & 8.0 & $\mathrm{j}$ & 20.3 & $\mathrm{~m}$ & 1.8 & $\mathrm{j}$ & 7.2 & o & 71.0 & $\mathrm{a}$ \\
\hline $\mathrm{V}_{1} \mathrm{~L}_{3}$ & 37.0 & $\mathrm{~h}$ & 113.0 & g & 12.0 & $\mathrm{~h}$ & 23.6 & 1 & 2.2 & $\mathrm{~h}$ & 8.9 & $\mathrm{kl}$ & 50.3 & d \\
\hline $\mathrm{V}_{1} \mathrm{~L}_{4}$ & 30.4 & $\mathrm{n}$ & 108.3 & $\mathrm{i}$ & 13.3 & $\mathrm{~g}$ & 24.4 & $\mathrm{kl}$ & 2.5 & $\mathrm{~g}$ & 8.6 & $\mathrm{~m}$ & 41.9 & $\mathrm{j}$ \\
\hline $\mathrm{V}_{1} \mathrm{~L}_{5}$ & 33.5 & $\mathrm{kl}$ & 110.3 & $\mathrm{~g}$ & 10.7 & $\mathrm{i}$ & 28.5 & gh & 2.2 & $\mathrm{~h}$ & 8.8 & $\mathrm{kl}$ & 47.0 & $\mathrm{~g}$ \\
\hline $\mathrm{V}_{1} \mathrm{~L}_{6}$ & 41.7 & $\mathrm{e}$ & 115.0 & $\mathrm{c}$ & 15.3 & ef & 30.7 & $\mathrm{e}$ & 2.8 & ef & 9.1 & $\mathrm{j}$ & 17.4 & $\mathrm{p}$ \\
\hline $\mathrm{V}_{1} \mathrm{~L}_{7}$ & 31.8 & $\mathrm{~m}$ & 106.3 & $\mathrm{k}$ & 10.0 & $\mathrm{i}$ & 25.2 & $\mathrm{jk}$ & 2.0 & $\mathrm{i}$ & 8.6 & $\operatorname{lm}$ & 30.0 & $\mathrm{~m}$ \\
\hline $\mathrm{V}_{2} \mathrm{~L}_{1}$ & 46.2 & $\mathrm{~b}$ & 116.3 & $\mathrm{~b}$ & 18.3 & $\mathrm{~b}$ & 36.6 & $\mathrm{~b}$ & 3.2 & $\mathrm{bc}$ & 10.4 & $\mathrm{c}$ & 5.4 & $\mathrm{t}$ \\
\hline $\mathrm{V}_{2} \mathrm{~L}_{2}$ & 27.7 & o & 98.3 & $q$ & 10.7 & $\mathrm{i}$ & 24.0 & 1 & 2.0 & $\mathrm{i}$ & 7.9 & $\mathrm{n}$ & 70.0 & $\mathrm{~b}$ \\
\hline $\mathrm{V}_{2} \mathrm{~L}_{3}$ & 38.0 & $\mathrm{~g}$ & 109.3 & $\mathrm{~h}$ & 14.7 & $\mathrm{f}$ & 27.3 & $\mathrm{i}$ & 2.5 & $\mathrm{~g}$ & 9.6 & gh & 49.3 & e \\
\hline $\mathrm{V}_{2} \mathrm{~L}_{4}$ & 31.8 & $\mathrm{~m}$ & 104.3 & $\mathrm{~m}$ & 16.0 & de & 28.1 & hi & 2.8 & ef & 9.2 & $\mathrm{j}$ & 40.9 & $\mathrm{k}$ \\
\hline $\mathrm{V}_{2} \mathrm{~L}_{5}$ & 34.5 & $\mathrm{j}$ & 106.3 & $\mathrm{k}$ & 13.3 & $\mathrm{~g}$ & 32.2 & $\mathrm{~d}$ & 2.5 & $\mathrm{~g}$ & 9.5 & hi & 46.0 & $\mathrm{~h}$ \\
\hline $\mathrm{V}_{2} \mathrm{~L}_{6}$ & 42.4 & $\mathrm{e}$ & 111.3 & $\mathrm{f}$ & 17.7 & $\mathrm{bc}$ & 34.7 & $\mathrm{c}$ & 3.0 & $\mathrm{~d}$ & 9.8 & fg & 16.4 & $q$ \\
\hline $\mathrm{V}_{2} \mathrm{~L}_{7}$ & 32.7 & 1 & 102.3 & $\mathrm{n}$ & 12.7 & $\mathrm{gh}$ & 28.8 & gh & 2.3 & $\mathrm{~h}$ & 9.3 & $\mathrm{ij}$ & 29.0 & $\mathrm{n}$ \\
\hline $\mathrm{V}_{3} \mathrm{~L}_{1}$ & 47.5 & $\mathrm{a}$ & 112.0 & $\mathrm{e}$ & 20.3 & $\mathrm{a}$ & 39.8 & $\mathrm{a}$ & 3.4 & $a b$ & 11.3 & $\mathrm{a}$ & 4.4 & $\mathrm{u}$ \\
\hline $\mathrm{V}_{3} \mathrm{~L}_{2}$ & 28.3 & o & 94.0 & $\mathrm{r}$ & 12.7 & gh & 26.1 & $\mathrm{jk}$ & 2.2 & $\mathrm{~h}$ & 8.7 & $\operatorname{lm}$ & 69.0 & $\mathrm{c}$ \\
\hline $\mathrm{V}_{3} \mathrm{~L}_{3}$ & 39.4 & $\mathrm{f}$ & 105.0 & 1 & 16.7 & $\mathrm{~cd}$ & 29.5 & fg & 2.7 & $\mathrm{f}$ & 10.4 & $\mathrm{c}$ & 48.3 & f \\
\hline $\mathrm{V}_{3} \mathrm{~L}_{4}$ & 33.1 & 1 & 100.0 & $\mathrm{p}$ & 18.0 & $\mathrm{~b}$ & 30.3 & ef & 3.0 & $\mathrm{~d}$ & 10.1 & $\mathrm{e}$ & 39.9 & 1 \\
\hline $\mathrm{V}_{3} \mathrm{~L}_{5}$ & 35.9 & $\mathrm{i}$ & 102.0 & $\mathrm{n}$ & 15.3 & ef & 34.3 & $\mathrm{c}$ & 2.7 & $\mathrm{f}$ & 10.3 & $\mathrm{~cd}$ & 45.0 & $\mathrm{i}$ \\
\hline $\mathrm{V}_{3} \mathrm{~L}_{6}$ & 43.7 & $\mathrm{~d}$ & 107.0 & $\mathrm{j}$ & 19.7 & $\mathrm{a}$ & 37.4 & $\mathrm{~b}$ & 3.3 & $a b$ & 10.7 & $\mathrm{~b}$ & 15.4 & $\mathrm{r}$ \\
\hline $\mathrm{V}_{3} \mathrm{~L}_{7}$ & 34.0 & $\mathrm{jk}$ & 98.0 & $q$ & 14.7 & $\mathrm{f}$ & 31.0 & $\mathrm{e}$ & 2.5 & $\mathrm{~g}$ & 10.1 & de & 28.0 & o \\
\hline LSD0.05 & 0.8 & & 0.6 & & 1.1 & & 1.1 & & 0.1 & & 0.2 & & 0.1 & \\
\hline CV\% & 1.4 & & 0.3 & & 4.5 & & 2.1 & & 3.4 & & 1.4 & & 0.1 & \\
\hline
\end{tabular}

Bending percentage of flower stick differed significantly with the gerbera varieties, treatments and their combinations. For the varietal response, maximum bending $(37.7 \%)$ occurred in $\mathrm{V}_{3}$, followed by $\mathrm{V}_{2}(36.7 \%)$, while minimum $(35.7 \%)$ in $\mathrm{V}_{1}$ (Table 1a). Conversely, $\mathrm{L}_{2}$ provided maximum bending $(70.0 \%)$ followed by $\mathrm{L}_{3}(49.3 \%)$, whereas minimum $5.4 \%$ from $\mathrm{L}_{1}$ and $16.4 \%$ from $\mathrm{L}_{6}$ (Table $1 \mathrm{~b}$ ) in terms of treatments. Among the combinations, $\mathrm{V}_{3} \mathrm{~L}_{1}$ provided the minimum bending (4.4\%) followed by $\mathrm{V}_{2} \mathrm{~L}_{1}(5.4 \%)$ and $\mathrm{V}_{1} \mathrm{~L}_{1}(6.4 \%)$, on the other hand, maximum bending provided by $\mathrm{V}_{1} \mathrm{~L}_{1}(71.0 \%)$ followed 
by $\mathrm{V}_{2} \mathrm{~L}_{1}(70.0 \%)$ and $\mathrm{V}_{3} \mathrm{~L}_{1}(69.0 \%)$ (Table 1c). $\mathrm{V}_{3}$ showed the minimum flower stalk bending characteristics; can be denoted as the best among the varieties exploited on experiment. Besides, protection of individual light wave length caused more flower stalk bending.

\section{CONCLUSION}

Among the gerbera cultivars $\mathrm{V}_{3}$ provided maximum leaf area $\left(37.9 \mathrm{~cm}^{2}\right)$, chlorophyll $(37.4 \%)$, number of flowers $(16.7)$, peduncle length $(32.6 \mathrm{~cm})$ and diameter $(2.8 \mathrm{~mm})$, flower head diameter $(10.2 \mathrm{~cm})$, while least from $\mathrm{V}_{1}$. Minimum number of leaves (29.0), plant height $(33.9 \mathrm{~cm})$, days to flower bud initiation (102.6), bending (35.7\%) were found in $\mathrm{V}_{3}$, whereas maximum in $\mathrm{V}_{1}$. On the other hand, $\mathrm{L}_{1}$ provided maximum number of leaves (35.2), leaf area $\left(42.0 \mathrm{~cm}^{2}\right)$, chlorophyll content (46.2\%), number of flower (18.1), peduncle length $(36.2 \mathrm{~cm})$ and diameter $(3.2 \mathrm{~mm})$, flower head diameter $(10.5 \mathrm{~cm})$ with minimum bending $(5.4 \%)$ followed by $\mathrm{L}_{6}$ whereas least from $\mathrm{L}_{2}$ with maximum bending. $\mathrm{V}_{3} \mathrm{~L}_{1}$ was the best while $\mathrm{V}_{1} \mathrm{~L}_{2}$ was the lowest among the treatment combinations. From the above result and discussion it can be concluded that $620-750 \mathrm{~nm}$ wavelength (red band) of light is a vital fact for growth and flowering of gerbera; $620-750 \mathrm{~nm}$ wavelength (red band) and 450 - $495 \mathrm{~nm}$ wavelength (blue band) is important for quality flower production of gerbera.

\section{REFERENCES}

Ambad, S. N., M. C. Bankar, A. L. Mulla, N. J. Takur and R. L. Takate. 2001. A new low cost polyhouse techniques for gerbera cultivation. Ind. Hort. 46(1): 16-17.

Cleland, C. and W. Briggs. 1967. Effect of low-intensity red and far-red light and high-intensity white light on the flowering response of the long-day plant lemna gibba G3. Plant Physiol. 43(2): 157-162.

Cybularz-Urban, T., E. Hanus-Fajerska and A. Swiderski. 2007. Effect of light wavelength on in vitro organogenesis of a cattleya hybrid. Acta Biologia Cracoviensia Series Botanica 49 (1): $113-118$

Das C., F.H. Shammy, S.U. Habiba, M.S. Islam and A.F.M. Jamal Uddin. 2012. Growth and yield performance of exotic potted gerbera cultivars (Gerbera jamesonii 1.) in Bangladesh. Bangladesh Res. Pub. J. 7(1): 16-20.

Devlin, R. 1975. Plant Physiology. $3^{\text {rd }}$ Ed. New York, NY. pp. 600.

Eberhardt, M. 1982. New high yielding and long lasting gerbera varieties. Gartenbau 29(10): 314316.

Gomez, K. H. and A. A. Gomez. 1984. Statistical Procedures for Agricultural Research. $2^{\text {nd }}$ Ed. Wiley- Inter Science Publication, John Wiley, New York. pp. 680.

Hopkins, W. G. 1999. Introduction to Plant Physiology. 2nd ed. New York, NY: John Wiley \& Sons, Inc. pp. 512.

Hunter, D. and D. Burritt. 2004. Light quality influences adventitious shoot production from cotyledon explants of lettuce (Lactuca sativa L.). In Vitro cellular and developmental biology. Plant Physiol. 40(2): 215-220. 
Jeevatothi, L., G. Balkrishnamoorthy, R. Murgesan, K. Rajamani and V. A. Sathyamurthy. 2003. Performance of gerbera under different growing structures. South Ind. Hort. 51(1-6): 66-69.

Kandpal, K., Santosh, R. Shrivastava and S. Ramchandra. 2003. Evaluation of gerbera (Gerbera jamesonii) cultivars under tarai condition. J. Ornamental Horticult. 6(3): 252-255.

Latkowska M., H. Kvaalen and M. Appelgren. 1999. Genotype Dependent Blue and Red Light Inhibition of the Proliferation of the Embryogenic Tissue of Norway Spruce. In vitro cellular and developmental biology. Plant Physiol. 36 (1): 57-60.

Marrs, K., and L. Kaufman. 1988. Blue-light regulation of transcription for nuclear genes in pea. Proceedings of the National Academy of Sciences of the United States of America 86(12): $4492-4495$

Moore, R., W.D. Clark and D.S. Vodopich. 2003. Botany. New York, NY: McGraw-Hill Companies, Inc. pp. 136-137.

Rajasekhar V. and S. Sopory. 1985. The Blue Light effect and its interaction with Phytochrome in the Control of Nitrite Reductase activity in Sorghum bicolor Willd. New Phytologist 101(2): 251-258.

Shahak, Y., E. E. Gussakovsky, E. Gal and R. Ganelevin. 2004. Color Nets: Crop protection and light-quality manipulation in one technology. Acta Hort. 659: 143-151.

Talbott, L., G. Nikolova, A. Ortiz, I. Shmayevich and E. Zeiger. 2002. Green light reversal of bluelight-stimulated stomatal opening is found in a diversity of plant species. American J. of Botany 89(2): 366-368.

Whiting, D. 2007. Plant growth factors: Light. Colorado State University Extension. Colorado State University Extension, USA.

Yerima, B. M. A. Esther, J. S. Madugu, N. S. Muwa and S. A. Timothy. 2012. The effect of light color (wavelength) and intensity on vegetable roselle (Hibiscus sabdariffa) growth. Scholarly J. of Scientific Research and Essay 1(2): 19-29. 